\title{
A Review of Methods to Improve Nitrogen Use Efficiency in Agriculture
}

\author{
Lakesh K. Sharma ${ }^{1,2, *}$ and Sukhwinder K. Bali 1,2,* \\ 1 Department of Cooperative Extension, University of Maine, 57 Houlton Rd., Presque Isle, ME 04769, USA \\ 2 Department of Art and Science, University of Maine at Presque Isle, 181 Main St, \\ Presque Isle, ME 04769, USA \\ * Correspondence: lakesh.sharma@maine.edu (L.K.S.); sukhwinder.bali@maine.edu (S.K.B.)
}

Received: 16 November 2017; Accepted: 23 December 2017; Published: 26 December 2017

\begin{abstract}
Management of nitrogen $(\mathrm{N})$ is a challenging task and several methods individually and in combination are in use to manage its efficiency. However, nitrogen use efficiency (NUE) has not been improved to a level, only $33 \%$, as predicted by the researchers while developing nitrogen management tools and methods. The primary objective of this review article is to evaluate methods and tools available to manage nitrogen. Several methods, soil testing, plant tissue testing, spectral response, fertilizer placement and timing and vegetative indexes (leaf area index, and NDVI) through drones, handheld sensors, and satellite imagery were reviewed on the subject of user-friendly and effectiveness towards NUE. No single method was found sufficient to counter the nitrogen loss. Some methods were found time consuming and unsynchronized with $\mathrm{N}$ uptake behavior of particular crop, for example, plant tissue testing. Use of precision agriculture tools, such as GreenSeeker, Holland Crop Circle, drone, and satellite imagery, were found better compared to conventional methods such as soil testing, but these tools can only be used when the crop is up. Therefore, $\mathrm{N}$ management is possible only through inseason $\mathrm{N}$ application methods. When $70 \%$ of the applied nitrogen is used by the crops within 25-30 days after planting, for example, corn and potatoes, it is required to apply major $\mathrm{N}$ rates through inseason approach and some $\mathrm{N}$ at planting using soil test reports. In conclusion, this article strongly advocates using two or more methods in combination when managing $\mathrm{N}$.
\end{abstract}

Keywords: nitrogen; NUE; soil; precision agriculture tools

\section{Introduction}

Nitrogen $(\mathrm{N})$, an essential nutrient for growth and development of plants, is added to agricultural fields to boost crop yields but is also limiting in the aquatic ecosystems. For example, accelerated surface water eutrophication, algal blooms, hypoxia, and public health issues due to consumption of contaminated groundwater have been linked to enrichment of excess use of $\mathrm{N}$ (and/or phosphorous, $\mathrm{P}$ ) that can be lost to the environment through leaching to the groundwater, and transportation to the nearby surface waters via surface runoff or directly via tile drainage bypassing stream buffer [1]. In addition, significant fractions of the applied $\mathrm{N}$ are lost in the air through emission of ammonia $\left(\mathrm{NH}_{3}\right)$, which contributes to eutrophication and acidification when redeposited on the land; nitrous oxide $\left(\mathrm{N}_{2} \mathrm{O}\right)$ is a potent greenhouse gas; and nitric oxide (NO) plays a role in tropospheric ozone chemistry [2]. These losses can be reduced by adoption of appropriate methods or best management practices (BMPs) that increase the accessibility of $\mathrm{N}$ for plant use, enhance plants' $\mathrm{N}$ uptake ability, and match nutrient applications with agronomic needs. Thus, the challenge with farming would be balancing crop-nutrient requirements while minimizing losses to maintain a sustainable environment and economic benefits to the farmers. 
Use of any fertilizer, both inorganic and organic form, can pose a threat to the environment if misused. Total global consumption of $\mathrm{N}$ fertilizer was 112.5 million tons in 2015 and is projected to reach 118.2 million tonnes in 2019 (see Figure 1A) with world population growth (likely to reach 7.9-10.5 billion by 2050; Zhang et al., 2017) and the need for food, feed, fiber, and fuel (FAO, Washington, DC, USA, 2016). Of which, North America constituted 14.1 million tonnes in 2015, and the demand for $\mathrm{N}$ fertilizer is expected to reach 14.6 million tonnes in 2019 (see Figure 1B). Although large amounts of $\mathrm{N}$ fertilizers were used throughout the world, the recovery or efficiency of $\mathrm{N}$ fertilizers by crops in arable lands is relatively low, ranging from $25 \%$ to $50 \%$ of the applied $\mathrm{N}[3,4]$. Low nitrogen use efficiency (NUE) may lead to an alarming situation from environmental, economic, and resource conservation points of view, and suggests an urgent need for improving $\mathrm{N}$ use efficiency (NUE) of fertilizers. Apart from the increased use of $\mathrm{N}$, the rapid increase of fertilizer prices is a significant concern for farmers. For example, in maize, 3.6 million metric tons of $\mathrm{N}$ fertilizer are used per annum within the North Central US, about 12 states, at a cost of 600-800 million USD [5]. In 2014, the use of total $\mathrm{N}$ fertilizer reached to 5 million metric tons $(\mathrm{Mg})$ at an estimated cost of $500 \$ / \mathrm{Mg}$ or USD 2.5 billion for 15 US States [6]. Thus, the increased use and cost of $\mathrm{N}$ fertilizers in crop production is alarming. Improved NUE has the potential to increase yields and profits by $\$ 18.75$ per acre with minimal environmental impacts when growing grain crops [7]. Other crops should have similar benefits as well.

In this review, we discuss various factors controlling $\mathrm{N}$ use efficiency (NUE) and the methods which can improve NUE in agriculture minimizing environmental losses. To our knowledge, this review is the first to include a comprehensive assessment of research on methods associated with both organic and inorganic sources of supplemental $\mathrm{N}$ to improve NUE in different crops in a single work. We specify possible ways to improve NUE for future research.
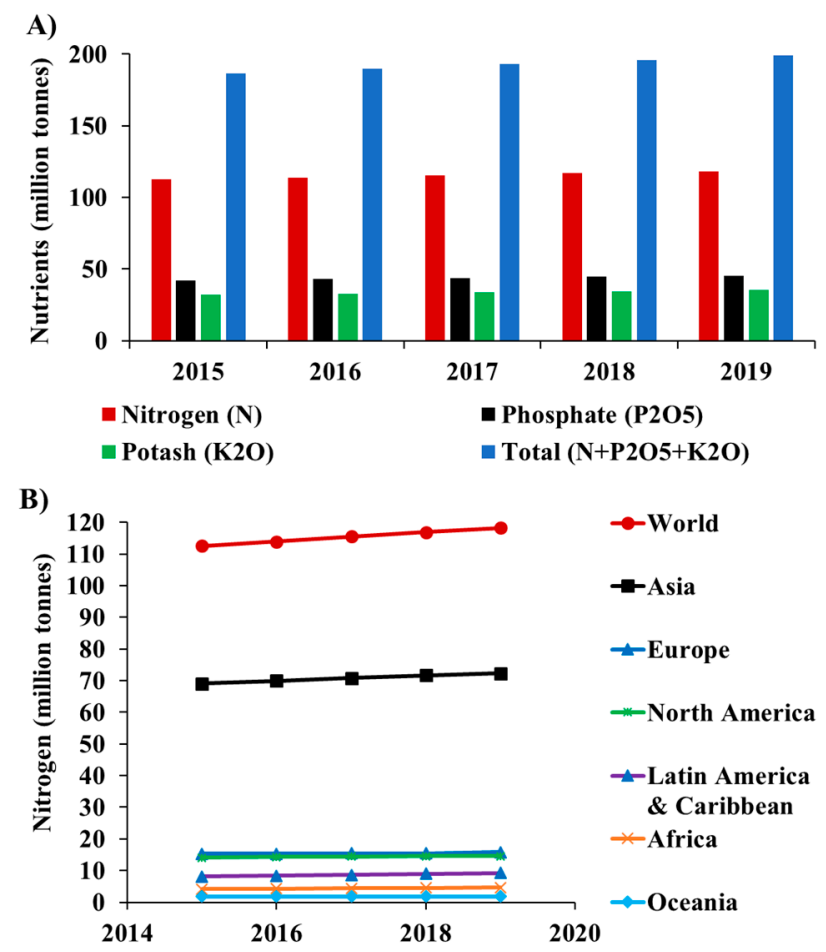

Figure 1. (A) World demand for the total fertilizer and three main plant nutrients (nitrogen, phosphate, and potash) forecasts, 2015-2019. (B) The world and regional demand for nitrogen fertilizer forecasts, 2015-2019. Adapted from FAO (2016). 


\section{Sources of Nitrogen and Interaction with Plant-Soil System}

Nitrogen is an element that can theoretically appear almost everywhere. In the atmosphere, $\mathrm{N}$ is dinitrogen gas $\left(\mathrm{N}_{2}\right)$, about $78 \%$ (4000 trillion tons) of the total gas. Dinitrogen is converted to different forms such as ammonium and nitrate by organisms [8]. About $95 \%$ of nitrogen is found in undisturbed natural soil organic matter [8]. However, when considering this element from an agricultural point of view, specific sources of nitrogen contribute the vast majority of the nitrogen available to crops and other plants. These sources include natural or organic sources and those generated from artificial processes.

Natural sources of nitrogen include those found sequestered in soils via mineralization and bacterial fixation [9]. The forms of nitrogen available to plants in soil are ammonium and nitrate [10]. Nitrite, nitrous oxide, and atmospheric nitrogen are also found in soil, although these are not forms of nitrogen that are naturally accessible by plants unless they are altered to ammonium or nitrate via bacterial fixation or lightning fixation [10]. Another natural source of nitrogen is sequestered in living organisms. When organisms die, they begin to decay and deposit nitrogen back into soils. Leguminous crops and animal carcasses both tend to contain more nitrogen than most other organisms and therefore serve well as natural fertilizers [11,12]. Leguminous crops are used in crop rotations, that is, to fix atmospheric nitrogen and later deposit it into the upper layers of agricultural soils. High levels of nitrogen in animal bones or bone meal are used as an effective alternative fertilizer to chemical ones [13,14].

Anhydrous ammonia $\left(\mathrm{NH}_{3}\right)$ is made of one part nitrogen and three parts hydrogen chemically. Anhydrous ammonia is the cheapest form of nitrogen fertilizer extensively used with easy application and ready availability but is also a caustic, toxic, and explosive gas. Strict regulations, therefore, exist concerning the use of this fertilizer in the United States [15]. Urea contains $46 \%$ nitrogen and is broadly used in agricultural as fertilizer. Urea is easily deposited in granules and therefore is preferable for windy climates. In soil, urea breaks down to ammonium $\left(\mathrm{NH}_{4}{ }^{+}\right)$ions and $\mathrm{CO}_{2}$. With proper care, urea is an excellent source of nitrogen for crop production. Ammonium nitrate is made up of nitrate and ammonium cation with chemical formula $\mathrm{NH}_{4} \mathrm{NO}_{3}$. Both ammonium and nitrate are available forms of nitrogen for plants; ammonium nitrate is merely the combination of both and is used as stable high nitrogen fertilizer, commonly in low $\mathrm{pH}$ and less windy climates due to its underlying structure [16].

Ammonium sulfate $\left[\left(\mathrm{NH}_{4}\right)_{2} \mathrm{SO}_{4}\right]$ was one of the first $\mathrm{N}$ fertilizer produced, over 150 years ago (IPNI, nutrient source specifics, Ref\#11-10072, No. 12). Ammonium sulfate has N (21\%) and sulfur (S) $(24 \%)$ that are more concentrated and efficiently handled. Ammonium sulfate is an excellent source of $\mathrm{N}$ as well as $\mathrm{S}$, which plays an essential role in plants function, such as protein synthesis. Ammonium sulfate is the most popular fertilizer in Maine, and tends to decrease $\mathrm{pH}$ but also increase sulfur content in soils, making it a preferable option when additional sulfur is also required for sufficient crop growth and health [17].

\section{What Is NUE, and How Can It Be Managed?}

Nitrogen use efficiency (NUE) is a somewhat general term that requires definition. To begin, it is primarily an agricultural term. It has two essential definitions, both are meant simultaneously when the term is used. The first definition of nitrogen use efficiency is the efficiency with which plants use and retain the nitrogen in the soil. The reason this definition for NUE is used is the tendency of a plant to release nitrogen as nitrous oxide into the atmosphere after absorption, rather than storing the nitrogen in its body [18]. Leguminous crops have a high NUE because they gather and store nitrogen in their bodies rather than release it into the atmosphere [11,12]. There is still much debate, however, as to whether the net loss of nitrogen is less with legumes than with other crops, as some is lost during decomposition of both leguminous and other crops [19]. NUE measures how much nitrogen a plant uptakes as well as how much of this nitrogen uptake is lost via nitrous oxide emissions from the plants. This measures how efficiently plants use and retain nitrogen. All of the nitrogen a plant gains is considered as soil nitrogen and all nitrous oxide emissions is considered to originate in the soil before 
a plant absorbs the nitrogen used to generate the nitrous oxide, since plants can absorb and utilize ammonium and nitrate forms of nitrogen through their roots [20]. This method of measuring NUE corresponds with the first definition of nitrogen use efficiency.

The second definition of NUE is the efficiency with which nitrogen applied to soils, through natural or artificial means, is taken up by plants and not used for other purposes such as feeding anaerobic bacteria that cause denitrification or leeching via nitrogen dissolution in water [21]. Nitrogen dissolution in water is often caused by over-application of fertilizers, excessive soil drainage (often caused by a lack of organic material), or inclined growing [22]. Anaerobic denitrification is caused by an excess of water in fields [23]. NUE measures the amount of nitrogen in growing soil at the start of a season, via soil samples and lab analysis, how much of this nitrogen was fixed [20], how much was lost via leaching and denitrification, and how much nitrogen is remaining in the soil. The more nitrogen the crop's uptake compared to the amount left in the soil or lost, the more nitrogen use efficient the system is. This is especially important when considering the use of fertilizers since the ideal situation is for no fertilizer to be wasted and for all of it to be absorbed to the benefit of the crops the fertilizer is used on [24].

Overall, Nitrogen use efficiency (NUE) is the efficient use of nitrogen. Nitrogen use efficiency is the amount of nitrogen a crop takes in and retains until harvest compared to the amount of nitrogen that was actually available for the crop to consume, with a particular emphasis on how much fertilizer is applied to soils compared to how much nitrogen crop intakes and retains until harvest (Raun and Johnson, 1999) [25]. Nitrogen use efficiency (NUE) has been widely used as a metric to relate N uptake with the quantity of $\mathrm{N}$ applied. One way to explain NUE is regarding the mass of grain harvested compared to the mass of $\mathrm{N}$ applied. Because of variability in yield potential, $\mathrm{N}$ loss potential within fields, and volatility in $\mathrm{N}$ fertilizer and corn prices over time, it is important to develop fertilization practices that can optimize the $\mathrm{N}$ fertilizer rates.

NUE is a complex trait. Nitrogen use efficiency is considered to be quite low on average in conventional agricultural systems around the world [25], including developed nations. Worldwide, nitrogen fertilizer use has increased drastically, from just over 79 million pounds in 2002 to about 99 million pounds in 2012 (Figure 2). However, world crop yields have hardly increased in proportion to the nitrogen fertilizer applied to these crops. This demonstrates a vast inefficiency of nitrogen fertilizer use. The NUE for world cereal production is low with estimates averaging $33 \%$ of fertilizer nitrogen $(\mathrm{N})$ recovered by the crop [25]. The prime cause of $\mathrm{N}$ loss is through nitrate leaching or denitrification from excessive rainfall. Typically, farmers applying $N$ before planting [26] in Missouri report that $\mathrm{N}$ application in the fall is at significant risk for spring $\mathrm{N}$ loss, which results in crop yield loss. The time between $\mathrm{N}$ application and its active absorption by the crop provides numerous opportunities for $\mathrm{N}$ loss from leaching, clay fixation, immobilization, denitrification, and volatilization [26].

Low NUE of current $\mathrm{N}$ management practices is partly due to the poor synchrony between the $\mathrm{N}$ application and crop demand $[25,27,28]$. Bulky pre-plant $\mathrm{N}$ applications cause poor synchronization. For example, an average $\mathrm{N}$ application in Corn Belt Region of the USA during the past twenty years is approximately $150 \mathrm{~kg} \mathrm{ha}^{-1}$ [6] with $75 \%$ of the applications made before planting (including the previous fall) [27]. During the first three weeks following emergence, corn uses soil mineral $\mathrm{N}$ at the rate of less than $0.5 \mathrm{~kg} \mathrm{ha}^{-1}$ day $^{-1}$. However, after the first three weeks, the corn plant takes up exponentially more $\mathrm{N}$ until tassels, with an average of $3.7 \mathrm{~kg} \mathrm{ha}^{-1}$ day ${ }^{-1}$ [29] and highest daily uptake of $6 \mathrm{~kg} \mathrm{ha}^{-1}$ day $^{-1}$ (J.S. Schepers, personal communication).

Depending on soil and weather conditions, pre-plant $\mathrm{N}$ could leach below the crop rooting zone early in the season before peak $\mathrm{N}$ uptake [30]. Therefore, large pre-plant $\mathrm{N}$ applications result in high levels of available $\mathrm{N}$ in the soil profile before actual active plant uptake, which is at risk of loss over several weeks. The efficiency of a single pre-plant $\mathrm{N}$ application decreases with the rate of $\mathrm{N}$ fertilizer applied [31]. On the other hand, in-season $\mathrm{N}$ application results in improved NUE as compared to pre-plant $\mathrm{N}$ application [32]. Supplying $\mathrm{N}$ as the crop requires could increase NUE [33]. 
Another factor that contributes to low NUE is uniform N application rates to spatially and/or temporarily variable landscapes, even though several studies have shown economic and environmental reasons for spatially variable $\mathrm{N}$ applications $[26,34]$. Soil $\mathrm{N}$ availability, crop $\mathrm{N}$ uptake, and $\mathrm{N}$ responses differ spatially within fields [35]. Consequently, large amounts of $\mathrm{N}$ applied as pre-plant into the field at a uniform rate is at risk for environmental loss in areas of over-application or soils at risk for loss. Another reason for low NUE is outdated N recommendations that promote over-application of N.

Several approaches have been used to determine actual $\mathrm{N}$ requirement of any crop, but, due to uncertainty in its calculation methods, $\mathrm{N}$ efficiency is low.

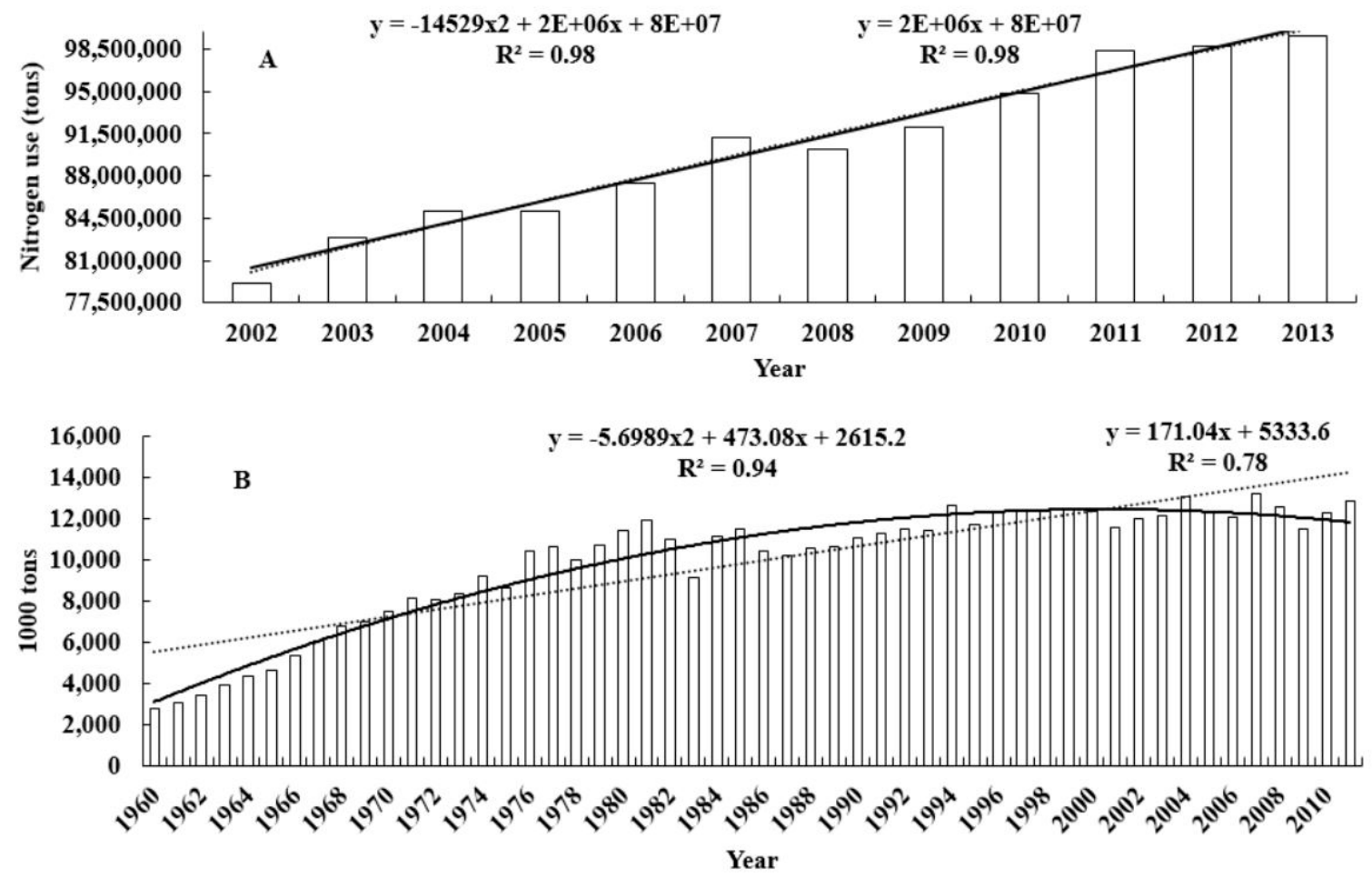

Figure 2. (A) The use of nitrogen across the years throughout the world; and (B) the food production increase over the years throughout the world.

\subsection{Soil Test Approach}

Soil and plant analysis is used for $\mathrm{N}$ management of different crops [30]. Current $\mathrm{N}$ management practices in the USA are based on several soil analysis components. Some states include soil organic matter (Nebraska, North Dakota, Missouri and Minnesota), nitrate-nitrogen credit from the previous crop (Nebraska, Illinois, Iowa, North Dakota, South Dakota and Minnesota), yield goal (Nebraska, South Dakota and North Dakota), and N credit from nitrogen from manure and irrigation water [36].

To supply the required amount of $\mathrm{N}$ with consideration of spatial variability, some studies [37] have encouraged a soil-based approach of outlining spatial variable management zones (MZ) for variable $\mathrm{N}$ applications and improving NUE. MZ are field areas with similar attributes in landscape and soil condition. Zones are considered homogeneous when they have similar electrical conductivity (EC), crop yield, and producer-defined areas [38,39]. Such attributes tend to have similar yield potential, input-use efficiency, and environmental impact from the application of fertilizers.

Researchers have suggested a variety of approaches for defining MZ boundaries. Geo-referenced data layers (i.e., soil color, electrical conductivity, yield, and topography) are statistically clustered or combined using geospatial statistical analyses within geographic information systems (GIS) to delineate zone boundaries [40]. Soil mapping units [41], remote sensing [40], topography [42], yield maps, and soil EC [37] have been used successfully to delineate the MZ. Most of the delineation of MZ 
depends upon the sources that are static and less consistent because of the temporal variation in yield potential $[43,44]$. Therefore, they might not be adequate alone to account for all of the variability of $\mathrm{N}$ requirement in a field.

A standard approach of $\mathrm{N}$ requirement in the main commercial crops is determined by a formula that includes yield expectations, soil test nitrate analysis before planting to $60-\mathrm{cm}$ in depth, and any $\mathrm{N}$ credits from previous crops (Table 1). The efficient use of $\mathrm{N}$ for commercial crop production is vital to maximize economic return and minimize $\mathrm{N}$ losses to the environment. Nitrogen use efficiency (NUE) has been widely used as a metric to relate $\mathrm{N}$ uptake with the quantity of $\mathrm{N}$ applied. One way to explain NUE is regarding the mass of grain harvested compared to the mass of $\mathrm{N}$ applied. Because there are considerable yield variability and $\mathrm{N}$ loss potential variability within fields, and volatility in $\mathrm{N}$ fertilizer prices and crop prices over time, developing fertilization practices that can optimize the $\mathrm{N}$ fertilizer rates in-season could enhance grower profitability and NUE.

Table 1. North Dakota State University Fertilizer Recommendation tables for $\mathrm{N}$ credit from previous crops.

\begin{tabular}{cc}
\hline Previous Crop & Credit \\
\hline Soybean & $45 \mathrm{~kg} \mathrm{ha}^{-1}$ \\
Edible bean & $45 \mathrm{~kg} \mathrm{ha}^{-1}$ \\
Pea and lentil & $45 \mathrm{~kg} \mathrm{ha}^{-1}$ \\
Chickpea & $45 \mathrm{~kg} \mathrm{ha}^{-1}$ \\
Sweet clover that was harvested & $45 \mathrm{~kg} \mathrm{ha}^{-1}$ \\
\hline Alfalfa that was harvested and unharvested sweet clover: & \\
\hline$>5$ plants $/ \mathrm{m}^{2}$ & $168 \mathrm{~kg} \mathrm{ha}^{-1}$ \\
34 plants $/ \mathrm{m}^{2}$ & $112 \mathrm{~kg} \mathrm{ha}^{-1}$ \\
12 plants $/ \mathrm{m}^{2}$ & $56 \mathrm{~kg} \mathrm{ha}^{-1}$ \\
$<1$ plant/m & $0 \mathrm{~kg} \mathrm{ha}^{-1}$ \\
\hline Sugar beet & \\
\hline Yellow leaves & $0 \mathrm{~kg} \mathrm{ha}^{-1}$ \\
Dark green leaves & $90 \mathrm{~kg} \mathrm{ha}^{-1}$ \\
\hline
\end{tabular}

Source: Table 1 is adopted from D.W. Franzen's Extension Publication.

In addition, $\mathrm{N}$ recommendation excludes farmer experiences, regional climate, and cultural practices. Regional climate, including temperature and precipitation, affect the availability of $\mathrm{N}$ to crops and the mineralization rate of residues and organic matter. Soils within a field also have varying characteristics (texture, $\mathrm{pH}$, and organic matter content) that affect $\mathrm{N}$ loss through enabling leaching or denitrification in years of excessive rainfall and $\mathrm{N}$ mineralization rate. Ideally, the $\mathrm{N}$ added during a given growing season would be equally climate-sensitive and site-specific [45].

Estimation of crop biomass yield is sometimes used for $\mathrm{N}$ rate determination with $\mathrm{C} 4$ plants. For example, corn requires less $\mathrm{N}$ for a given amount of biomass compared to $\mathrm{C} 3$ plants such as wheat [46]. Predicting crop yield is nearly impossible due to annual variation in precipitation and pollination period temperature, particularly in dryland cultivation. Various methods have been considered for trying to improve estimation of target yield. Yields may be averaged over some years to obtain a mean yield that is then used to calculate $\mathrm{N}$ rate application, but, while it reflects past yield, it is not an adequate predictor of future yields

Another technique for estimating target yield is to consider the yield results of recent years with favorable crop growing conditions. However, in years of poor growing conditions, $\mathrm{N}$ remains in the soil or is lost during the non-crop growing portion of the year. Target yield prediction has been suggested as the mean yield from the most recent five to seven years, with an additional $5 \%$ to $10 \%$ yield addition as "insurance" against under fertilization [47]. Many surveys have reported that most of the producers overestimate the target yield to determine the N requirement [48]. Similarly, studies in Wisconsin [49], Pennsylvania [50], and Ontario [51] have shown the problems of using yield 
expectation to predict $\mathrm{N}$ rate and consequently raise concern over its reliability and use for future $\mathrm{N}$ recommendations.

\subsection{Use of Tissue Analysis for N Management}

Another approach is to use sensitive plants as indicators of the nutrient status of the soil. Some crops are good indicators of the overall growing conditions as they are directly linked to the weather conditions and soil management practices [52]. Usually, increased $\mathrm{N}$ availability in plants results in more leaf $\mathrm{N}$ concentrations and thus more chlorophyll [52] and higher photosynthetic rate [53]. The chlorophyll content of the corn leaf as estimated by the chlorophyll meter is highly correlated with corn yield and $\mathrm{N}$ concentration in the leaf [54].

Nitrogen concentration in critical states can be used as an indicator of crop $\mathrm{N}$ status. Critical $\mathrm{N}$ is the minimum amount of $\mathrm{N}$ required to produce the maximum amount of growth at a particular time [55]. As a crop grows and develops, the concentration of $\mathrm{N}$ is first high, and then decreases with maturity. The graphical representation of this progression is called the critical $\mathrm{N}$ dilution [56]. The nitrogen nutrition index (NNI) is a ratio of the actual $\mathrm{N}$ in the plant to the critical $\mathrm{N}$ established by past experiments [46]. The value of NNI above or below 1 relates to a non-limiting growth or deficient situation of the crop, respectively. The NNI approach has been used in wheat (Triticum aestivum L.) [57], grain sorghum (Sorghum bicolor L.) [58], rice (Oryza sativa L.) [59], and grasses [60].

In corn and potatoes, the approach of critical $\mathrm{N}$ at the early growth stage does not provide a reliable estimate crop $\mathrm{N}$ status [61] and this could be due to the competition between plants [62]. The concentration of $\mathrm{N}$ decreases with increase in crop biomass, sometimes referred to as "dilution" [62]. The critical $\mathrm{N}$ dilution curve range for corn could be used up to the silage maturity [63]. The concept of critical N may be more practical in small-scale agricultural systems, but it is usually not practical for large-scale commercial agriculture.

\subsection{Spatial Variation}

Commercial crop production fields can be categorized by differences in soils, production history, soil management techniques, movement of water and nutrients that imposing spatial variability. These spatial differences cause differences in plant $\mathrm{N}$ requirement, susceptibility to stress, and variation in plant productivity across a landscape. Variations in slope within a landscape can have a substantial impact on grain yield variability [64]. Soil depth and drainage also have a significant impact on corn grain and potato yield [65]. In commercial crop production, higher $\mathrm{N}$ fertility levels have been observed in foot slopes and depressions due to the flow of water and soil deposition of clay and organic matter to these landscape positions. This effect is most evident in soils with upper landscape positions that are low in organic matter [42]. Phosphorus and potassium concentrations also tend to have higher levels of plant availability in foot slopes and depressions, although higher crop removal with higher crop production history may produce lower $\mathrm{P}$ and $\mathrm{K}$ levels than expected [42]. The deposition and distribution of $\mathrm{P}$ and $\mathrm{K}$ may therefore not be as correlated with a slope as is organic matter [42].

Topography is an important factor explaining spatial variation in grain yield. Topography and slope helped to explain 30\% and 85\% variability in the yield of corn and soybean (Glycine max L.) cropping systems, respectively [66]. Although topography and soil properties offer some understanding of variability in grain yield, they are only two of many factors that contribute to variability

Crop stress results in a reduction of growth and yield. Seasonal weather conditions influence crops under variable landscapes. During a dry growing season or a wet growing season, differences in yield due to landscape position are magnified Landscapes having high organic matter and water holding capacity are less affected by drought conditions as compared to the upland areas [64]. Greater rainfall can cause yield decreases in depressions, where ponding can occur [67]. Decrease in soil organic matter and moisture because of structural degradation can result in stress, which intensifies spatial differences. 
Tillage and management practices across a landscape also influence plant growth and productivity. Increases in spatial variability have been observed in regions where reduced tillage and reduced chemical dependence were used [64,67].

\subsection{Fertilizer Placement and Timing}

Nitrogen is a crop nutrient that is commonly applied as fertilizer, and it is susceptible to many soil transformations. These transformations occur at the soil surface and within the soil, and the transformations can influence NUE. Leaching, runoff, and volatilization are significant loss avenues for N.

There is need of $\mathrm{N}$ application in ways that ensure a high level of $\mathrm{N}$ availability to the crop with high NUE. Broadcasting UAN (urea-ammonium nitrate solutions) results in lower yields than injected UAN, particularly on fields with surface residue [68,69]. Loss of $\mathrm{N}$ using broadcast UAN includes volatilization of ammonia from the urea part of the solution and immobilization of $\mathrm{N}$ in the surface residue [69]. Therefore, fertilizer placement below the soil surface may often be more efficient.

In modern crop hybrids, approximately $15 \%$ of the total $N$ uptake and $5 \%$ of the total dry matter accumulation occurred at the V7 growth stage [70]. By silking, $60 \%$ of total $\mathrm{N}$ uptake has taken place, and $40 \%$ of total dry matter has accumulated. Therefore, a considerable amount, around $40 \%$, of the crop's total N uptake occurs during a 30-day period between V7 and VT. There are opportunities to improve $\mathrm{N}$ synchronization by delaying in-season $\mathrm{N}$ applications until $\mathrm{V} 7$ without compromising with yield [71].

Scharf et al. [26] experimented with 28 locations and over a variety of soils where the timing of $\mathrm{N}$ fertilizer was the experimental variable. A single application of ammonium nitrate was applied at a rate of $180 \mathrm{~kg} \mathrm{~N} \mathrm{ha}^{-1}$ at: (1) planting; (2) V7; (3) V14; or (4) silking stage. Corn yield responded positively to $\mathrm{N}$ fertilizer at the majority of locations. When all 28 trials were considered, there was little yield reduction with $\mathrm{N}$ applications delayed as late as V14. Climate might affect the relative risk of yield loss with late $\mathrm{N}$ application. In a dry year, for many locations, maximum yield was attained on water stressed corn by surface applying $\mathrm{N}$ as late as V14. A complication with this study is that many of the locations had been amended with animal manure; many others had soybean as a previous crop, and several different tillage systems were combined across the entire experiment. There were two non-manured locations under corn after corn, although both were tilled. Previous crop, manure management, and tillage management are known to affect $\mathrm{N}$ mineralization rates, soil-N supply and, therefore, the seriousness and timing of $\mathrm{N}$ deficiency.

Contrary to the general conclusions in [26], one of the sites experienced irreversible yield loss when $\mathrm{N}$ was applied on or after $\mathrm{V} 6$, which means that $\mathrm{N}$ availability at this site must be adequate before side-dressing to ensure that maximum yield is obtained. As the level of $\mathrm{N}$ deficiency increased, the grain yield response to $\mathrm{N}$ decreased with the more considerable delay in the side-dress $\mathrm{N}$ application, meaning that there was a definite interaction between the level of $\mathrm{N}$ deficiency and the time of $\mathrm{N}$ application on corn yield.

Binder et al. [72] examined $\mathrm{N}$ fertilizer timing in Nebraska on silty clay loam soil under double-disc tillage. The previous crop was sorghum for the first year and fallow for the second. Side-dress $\mathrm{N}$ at V8-V10 was one of the best ways of supplying $\mathrm{N}$ to corn. Soil $\mathrm{N}$ status affected how late the $\mathrm{N}$ application could be delayed without causing a yield reduction. Therefore, optimum $\mathrm{N}$ application time depends on the degree of $\mathrm{N}$ deficiency, which is related to both available soil $\mathrm{N}$ and the crop $\mathrm{N}$ demand. This was particularly true in the first year of this research, where the climate caused more severe $\mathrm{N}$ stress than in the second year. In Year 1, for the $0 \mathrm{~kg} \mathrm{~N}^{-1} \mathrm{~N}$ rate, $\mathrm{N}$ had to be applied before V6 to attain maximum yield, due to dry soils later in the season. In Year 2, with more soil moisture, the application at V16 resulted in similar yield as applications earlier in the season. 


\subsection{Leaf Area Index}

Leaf Area Index (LAI) is defined as the ratio of leaf surface area to ground surface area [73]. Leaf area index is a direct representation of the photosynthetic capacity of the vegetation [74]. For some species/communities, LAI may be directly related to vegetation productivity, but, for others, the relation of LAI to productivity depends on other variables such as light, canopy extinction coefficient, NUE, and the amount of light intercepted at the top of the canopy [75]. For example, C4 plants have higher NUE, when grown in dense stands, while C4 plants produce more leaf area than C3 plants grown under the same environmental conditions [75].

Several approaches have been developed to estimate LAI from remote sensing. The most commonly used are inversions of canopy radiative transfer models [76] and empirical relationships between LAI and spectral vegetation indices [77]. A short-coming of algorithms based on vegetation indices is the difficulty in extrapolating their results to larger regions or different canopy types [78]. Vegetation index predictions are often confounded with atmospheric and background effects, canopy architecture, solar-target-sensor geometry and lack of spectrum differences when measuring moderate to high levels of LAI [79].

\subsection{Spectral Response}

Environmental stresses result in leaf spectral property changes. Carter [80] observed similar changes in spectral responses across multiple species with changes in plant competition, disease interaction, insufficient ectomycorrhizal infection, senescence, herbicide damage, increased ozone, dehydration, and the presence of saline soils. The basis for these responses was that stress reduces chlorophyll content. Chlorophyll $a$ has relatively low absorbency in the green and red spectrums. Even small changes in chlorophyll concentration can cause increased reflection at these wavelengths [81]. Zhao et al. [82] found more than a 60\% reduction in chlorophyll $a$ in leaves after 42 days of emergence, resulting in increased reflectance near 550 and $710 \mathrm{~nm}$.

Micronutrient deficiencies could also induce stress similar to $\mathrm{N}$ deficiency. Masoni et al. [83] after evaluating $\mathrm{Fe}, \mathrm{S}, \mathrm{Mg}$, and $\mathrm{Mn}$ deficiencies in corn found that leaf chlorophyll concentrations decreased with decreasing micronutrient concentrations. Chlorophyll a concentration was $22 \%$ less when $\mathrm{Fe}, \mathrm{Mg}$, and $\mathrm{Mn}$ were deficient compared to unstressed plants. Sulfur deficiency resulted in a $50 \%$ reduction in chlorophyll $a$ concentration. The reduced chlorophyll concentrations resulted in decreased light absorbency and increased reflectance near 555 and $700 \mathrm{~nm}$ [83].

\subsection{Estimation of Vegetative Indexes}

\subsubsection{Nutrient Status}

Soil fertility affects corn growth, and nutrient deficiencies can be corrected with the application of fertilizers [84]. Numerous techniques have been used, including soil testing and destructive plant analysis, to determine plant nutrient status. Recently, the use of non-destructive sensors has been used to determine plant nutrient status [85]. Most of the sensor work has been devoted to crop N status [86].

Nitrogen deficiency reduces the photosynthetic rate of leaves. Corn production is often reduced due to low $\mathrm{N}$ availability producing lower kernel dry weight and a general reduction in all components of corn yield [87]. Selection of wavelengths relevant to corn $\mathrm{N}$ status is critical to determining corn $\mathrm{N}$ status $[84,86]$.

Shanahan et al. [88] proposed using NDVI and Green NDVI (GNDVI). In the GNDVI, the two spectra used were NIR, and the other was in the range of 500-600 nm. The light in this spectrum is green, therefore; it was named as green NDVI. The basis for their finding was an experiment on four corn hybrids under irrigation using five nitrogen rates. Active-optical sensors emitted light in four bands: blue $(460 \mathrm{~nm})$, green $(555 \mathrm{~nm})$, red $(680 \mathrm{~nm})$, and NIR $(800 \mathrm{~nm})$. Differences in NDVI were related to $\mathrm{N}$ rate and sampling date. Nitrogen treatment was correlated to increased chlorophyll 
content $\left(\mathrm{r}^{2} \geq 0.96\right)$. In addition, Hansen et al. [89] found that NDVI could be used successfully in evaluating growth and development of small grains.

\subsubsection{Yield Estimation}

Even though a relationship between vegetative indices and green leaf biomass has been established, Gitelson et al. [90] found the use of sensors in yield estimation difficult.

In wheat, sensor readings at Feekes growth stage 5 tended to be more correlated with grain yield than any other stage of development [91]. Raun et al. [92] found that sensor-based estimated grain yields could explain $83 \%$ of grain yield variability. The relationship between sensor reading and yield may be variable over space and time [93]. The inconsistencies in estimating yield have included sampling date, hybrid variation, seasonal changes, spatial differences, and $\mathrm{N}$ fertilization [93].

\subsection{Nitrogen Management Using Site-Specific Technologies}

Remote sensing measures information from an object or area without being destructive. Examples of remote sensors include ground-based active optical sensors, satellites imagery, aerial imagery or photography, ground-based reflective sensors and leaf chlorophyll sensors [94]. Remote sensing has been used in agriculture for estimating land use, land cover, and crop biomass [95]. Remote sensing techniques are now utilized to determine the spatial crop N status in-season [96]. Several studies have resulted in the development of the relationship between chlorophyll content, crop $\mathrm{N}$ status, and spectral reflectance [96]. Some of the first studies to utilize remote sensing techniques investigated the SPAD ${ }^{\circledR}$ (Konica-Minolta Americas, Ramsey, NJ, USA) chlorophyll meter, canopy reflectance or color photography (Blackmer et al., 1996b) [97].

Since the mid-1990s, a variety of geospatial technologies has been available to the agricultural market. Crop reflectance, color photography, and GBAO sensors have been successfully used to measure spatial variability in crop canopies [98].

\subsubsection{Use of Sensors and NDVI}

Most farmers apply $\mathrm{N}$ with consideration of previous crop, soil drainage, and soil management, but they do not use in-season tools for diagnosing an optimal $\mathrm{N}$ rate [99]. Farmers also tend to apply higher rates of $\mathrm{N}$ fertilizer than recommended to ensure maximum yield [100]. Excessive $\mathrm{N}$ rates for the yield attained often results in unused $\mathrm{N}$ moving to ground and surface water in the form of nitrate [100]. Use of proximal plant canopy sensors offers an opportunity for corn producers to adjust $\mathrm{N}$ requirement according to the crop requirement.

Determining the best $\mathrm{N}$ rate for a field and variety of corn is difficult. The concept of "need basis" using sensing tools was proposed by Schepers et al. [54] to aid in reducing environmental contamination from excess nitrate in corn production. This approach used the SPAD chlorophyll meter measurements, which helped estimate the crop $\mathrm{N}$ status against a standard color and then applying $\mathrm{N}$ as required. This technique contributed to maintaining the optimum yield with less fertilizer application [101]. The weakness of this approach was the need to physically gather tedious readings from many leaves and standardize the $\mathrm{N}$-sufficient plants from $\mathrm{N}$-deficient within multiple varieties.

The SPAD chlorophyll meter is an active optical sensor that measures transmitted light through the plant leaf at two different wavelengths, one in the near-infrared (NIR) and one in the red (RED) region of the light spectrum, and computes a value which is determined by the manufacturer. The meter is a non-destructive technology that helps to analyze leaf tissue for the assessment of the $\mathrm{N}$ status/nutrition of the plant. Studies showed that chlorophyll meter readings have positively correlated with chlorophyll content [54]. The SPAD meter, however, is placed onto one single leaf per measurement, which makes multiple readings in a field time-consuming.

Chlorophyll meter research on corn has focused on segregating locations with a positive response to $\mathrm{N}$ fertilizer from locations with low response potential, to indicate if and when $\mathrm{N}$ supplementation is needed [100]. Corn hybrid characteristics confound chlorophyll meter calibration and reduce the 
instrument's effectiveness in predicting $\mathrm{N}$ availability across large regions (Schepers et al., 1992) [54]. However, it is easy to normalize the meter data for a specific hybrid as well as growth stage, against a high-N nutrition control. If calibrated correctly in many hybrids, the instrument would be better able to permit comparisons across locations and growth stages. Commercial application of chlorophyll meter requires a reference strip, which is usually an adequately $\mathrm{N}$-fertilized area within the field under local growing conditions (Schepers et al., 1992) [54].

Bullock and Anderson [102] found no correlation between chlorophyll meter readings and yield at the V7 stage. However, at advanced stages (R1 and R4) they determined a better correlation between leaf $\mathrm{N}$ concentration and yield. At advanced stages ( $\mathrm{R} 1$ and $\mathrm{R} 4$ ), the meter readings were related more to the grain yield than leaf $\mathrm{N}$. The correlations coefficient between the meter readings and leaf $\mathrm{N}$ was positive at early stages $\left(\mathrm{r}^{2}=0.23\right)$ and decreased in value as growth advanced $\left(\mathrm{r}^{2}=0.20\right)$. Scharf (2001) [103] found that absolute rather than relative chlorophyll meter readings were taken at V6 were related strongly to the economically optimal nitrogen rate (EONR) and recommended lower $\mathrm{N}$ rates than used by producers in the same fields. Although the meter $\mathrm{N}$ rate recommendation did not increase crop profitability, profitability was maintained when compared with producer chose $\mathrm{N}$ rates. In contrast, Bullock and Anderson (1998) [102] concluded that absolute readings of chlorophyll meter could not be used for accurate $\mathrm{N}$ predictions in wheat.

Successful $\mathrm{N}$ recommendations have been developed in irrigated corn using relative chlorophyll meter readings (comparison of sensor readings between high $\mathrm{N}$ plot and standard farmer field), where irrigation water was used as an $\mathrm{N}$ delivery system. By continually checking corn $\mathrm{N}$ status with the meter, a low rate of $\mathrm{N}$ could be applied whenever meter readings fell below a critical value [101]. An area with a non-limiting $\mathrm{N}$ rate applied was required to produce the relative chlorophyll meter recommendations.

Scharf et al. [100] found that relative chlorophyll meter readings better-predicted corn grain yield than absolute meter readings. In dryland corn production systems, where the opportunity to make corrective $\mathrm{N}$ applications is restricted to one application, there is not an absolute relationship between chlorophyll meter readings and the $\mathrm{N}$ rate needed by the crop [100]. In contrast to irrigated systems where fixed low $\mathrm{N}$ rates can repeatedly be applied as needed, in dryland systems, the chlorophyll meter will only be useful in guiding $\mathrm{N}$ application rates if the meter can be the basis for that single corrective $\mathrm{N}$ rate recommendation [100].

Corn growers may benefit from a system that would convert reflectance measurements from vehicle-mounted sensors directly into an N application rate [104]. Ground-based active-optical (GBAO) sensors have been successfully used in winter wheat $\mathrm{N}$ management in Nebraska [105]. They can be used at any growth stage of the crop, depending on their light source, without consideration of clouds and ambient light. The GBAO sensors emit coded light of specific wavelengths onto the crop foliage. The modulated light pulses of a specific duration of each pulse, which when the pulses are sensed in the same pattern, and the light reflected back to the instrument. The modulation works on the same principle as in an infrared remote television controller. The instrument records the light that is reflected back to the sensor in the same pulse code. In a GBAO sensor using red and infrared light, the red NDVI is related to percent biomass, which in turn is related to predict crop yield. Differences between a known high-N yield within the field and yield predicted from the normal field can be used to predict the $\mathrm{N}$ required to increase the productivity of the area with lower yield prediction to the yield production of the high- $\mathrm{N}$ area.

Several studies have been conducted to measure the efficacy of two commercially available active optical sensors, GS Model 505 (Trimble, Inc., Sunnyvale, CA, USA), and CC ACS-210 ${ }^{\mathrm{TM}}$ (Holland Scientific, Inc., Lincoln, NE, USA) in predicting corn yield [106-109]. The basic differences between the two sensors are the use of different wavelengths to calculate NDVI. While both sensors use wavelengths in the visible and near-infrared spectrums, the GS Model 505 works with reflectance measurements from $660 \mathrm{~nm}$ to $770 \mathrm{~nm}$, whereas the CC ACS-210 emits and detects light at $590 \mathrm{~nm}$ and $880 \mathrm{~nm}$. Both sensors are sensitive to crop growth differences $\left(r^{2}>0.89\right)$. However, at later growth 
stages the GS Model 550 showed saturation compared to the CC ACS-210 because in CC ACS-210 different wavelength used to predict yield, thus making it less sensitive and more usable even at the later growth stages (Shaver et al., 2011) [110]. Additionally, GS was sensitive to row spacing and sensor speed [110]. In contrast, CC ACS-210 was found stable over early and late growth stages as well as across multiple row spacing and sensor movement speeds [111]. Therefore, while choosing an appropriate sensor variable $\mathrm{N}$ management, the red-edge $(680-730 \mathrm{~nm})$ and/or green wavelength $(590 \mathrm{~nm})$ provide a better estimation of canopy development $[110,111]$.

The hand-held GS 505 is also a GBAO sensor, which, unlike the chlorophyll meter, measures reflected light. The GS has significant advantages over the chlorophyll meter, satellite images and aerial photographs in managing corn $\mathrm{N}$ nutrition at a field scale including that it is faster and less labor-intensive than the chlorophyll meter. The GS also does not require a full canopy or ultra-high resolution as do aerial photographs [112].

The GS is an "active proximal" sensor, not limited by cloud cover or diurnal variation, and emits the light that is measured upon reflectance back to the sensor [113]. The light emitted at two different wavelengths, red $670 \mathrm{~nm}$ and NIR $780 \mathrm{~nm}$, have related mainly to canopy biomass and photosynthetic capacity [113]. Reflected red radiation always negatively correlated with canopy photosynthetic activity, whereas the NIR reflectance always positively related to canopy biomass [114].

Nitrogen deficient plants often exhibit higher levels of reflectance in the visible (400-700 nm) portion of the spectra due to reduced photosynthetic activity, and lower reflectance levels in the NIR $(>700 \mathrm{~nm})$ region explained by the reduced leaf surface area in the $\mathrm{N}$-stressed plants (Daughtry et al., 2000) [115]. In addition, leaf tissue is known to reflect more NIR radiation than most soil surfaces [115]. The GS instrument computes the NDVI as (NIR $780 \mathrm{~nm}$ - RED $670 \mathrm{~nm}$ )/(NIR $780 \mathrm{~nm}+$ RED $670 \mathrm{~nm}$ ). The NDVI readings were found to change temporally as a logarithmic function of the canopy biomass; however, after canopy closure, the biomass can continue to increase after NDVI reaches a maximum [116]. In other words, the NDVI becomes "saturated" after canopy closure $[116,117]$.

Raun et al. (2002) [105] and Mullen et al. (2003) [115] have shown that the GS NDVI value can be used to direct variable rate $\mathrm{N}$ applications to wheat and improve NUE. However, limitations to using of the GS during corn's in-season application window (V8 to R1) have been documented by Shanahan et al. [118], whereas NDVI became saturated at intermediate LAI values, the higher corn vegetative biomass makes sensor use in the red spectrum challenging [119].

Clay et al. [120], using the Cropscan ${ }^{\circledR}$ (Cropscan Inc., Rochester, MN, USA) sensor, could determine the influence of water and $\mathrm{N}$ stress on corn canopy light reflectance. They found that the relationship between reflectance and $\mathrm{N}$ or water stress changed due to corn growth stage and the wavelength utilized. By V11 to VT, canopy closure was complete. Additional N increased the values of all spectral indices tested while reducing reflectance in all the bands except the NIR. This suggested a low sensitivity in the NIR with $\mathrm{N}$ nutrition.

A comparison between three $\mathrm{N}$ fertilizer models showed that at about V8, $\mathrm{N}$ fertilizer recommendations based on NDVI were more predictive than recommendations based on expected yield or soil water yield prediction [120]. When corn was under water stress, the canopy reflectance was higher than non-stressed corn between V8 and VT [120]. The reflectance values increased over the visible spectral range under stressed corn canopy between V8 and VT growth stage; however, the change in reflectance was more significant in the green spectra than in the other bands. Clay et al. [120] concluded that green reflectance might be more sensitive to N stress than NIR, while red reflectance appeared to be more sensitive to water stress, as yield losses due to water stress correlated with reflectance in the green and red bands along with NDVI. Ultimately, they found that a green NDVI (GNDVI) index correlated better with corn grain yield than many other indices tested in the study. These conclusions have been supported by Shanahan et al. [118].

The transformed soil adjusted vegetative index (TSAVI) was proposed as an alternative index to deal with the problem of the changing influence of soil variability in the reflection of light when using an NDVI sensor. However, Shanahan et al. [121] concluded that NDVI was superior to TSAVI in 
detecting corn canopy variation. Green NDVI, which substitutes the red within the NDVI equation with the green wavelengths, was proposed by Gitelson et al. [116] to enhance the sensitivity of the NDVI and was found by Shanahan et al. (2001) [121] to distinguish corn canopy differences better. Martin et al. [122] used the GS with the red NDVI to conduct a study where the progression in temporal NDVI of the growing corn canopy was measured, and the spatial variability of corn growth over time was evaluated using the coefficient of variation statistic (CV). Corn grain and biomass yields were best related to NDVI when readings were obtained between V8 and V12. They found that this complementary approach, using both average NDVI value and the CV for that value within corn growth stage, could improve yield potential estimation compared to NDVI value alone.

Solari et al. [123] used the chlorophyll meter (CM) and CC ACS 210 sensor to evaluate NDVI using the green spectra $(590 \mathrm{~nm})$ and computed a CI as CI590 $=($ NIR/VIS590 $)-1$. They also examined when the readings should be taken and which index better-predicted corn grain yield. Greater $\mathrm{r}^{2}$ values were achieved when readings were taken during vegetative growth than during reproductive stage. This indicated that the presence of the tassel confounded the relationship between the CM values and sensor NDVI and CI values. The authors suggested that this might be due to the reduced ability of the sensor light source to penetrate further than the 5 th or 6 th leaf into the corn canopy when the reading was taken at the height of around $80 \mathrm{~cm}$ above the canopy. They also found that $\mathrm{CI}$ values were more sensitive than GNDVI values in assessing crop $\mathrm{N}$ status. Although the two sensor measurements were equally sensitive in assessing yield potential, the authors suggested that the CI would have a higher potential for directing spatially variable in-season $\mathrm{N}$ applications.

Freeman et al. [124], using the GS, performed plant measurements of NDVI and considered the possibility of complementing NDVI readings with plant height information for predicting corn forage yield and forage $\mathrm{N}$ uptake. He concluded that the best predictor of corn forage yield and $\mathrm{N}$ uptake was NDVI calculated alone at early stages (V7 to V9). Scharf and Lory [104], using the Cropscan ${ }^{\circledR}$ MSR87 multispectral radiometer (Cropscan, Inc., Rochester, MN, USA), conducted a study to calibrate reflectance measurements at V6 for prediction of the EONR for corn in Missouri. Many wavelengths were evaluated along with different sensor orientations. They found that best orientation of the sensor was facing downwards, with the sensor facing the crop canopy. They also reported that the proportion of soil captured in the sensor's field of view influenced reflectance measurements most with the downward orientation, suggesting that this soil interference may have aided in diagnosing soil $\mathrm{N}$ supply, due to the effects of $\mathrm{N}$ on plant size, soil cover, and soil contribution to the measured reflectance values. Their conclusions suggest that the relationship between reflectance and EONR might be different according to soil color.

Among the wavelengths evaluated by Scharf and Lory [104], the different NIR bands had no effect on $r^{2}$ for the relationship, while the selection of the band in the visible part of the spectrum significantly influenced $\mathrm{r}^{2}$. Simple relationships between NIR and VIS bands were no different from those among the different NDVI indices. The EONR was somewhat better correlated with GNDVI $\left(\mathrm{r}^{2}=0.66\right)$ than with NDVI $\left(\mathrm{r}^{2}=0.55\right)$. The authors concluded that $\mathrm{N}$ savings using their calibrations could be anticipated only when pre-plant $\mathrm{N}$ rates were limited, and the remaining $\mathrm{N}$ applied after crop establishment.

Kitchen et al. [113], using a CC ACS-210 sensor, conducted a study to evaluate the use of active optical sensors to assess corn $\mathrm{N}$ need and derived $\mathrm{N}$ fertilizer application rates that would return maximum profit to the grower's use of a single application rate at planting. The GNDVI was used with a sufficiency index (SI), the ratio of normal $\mathrm{N}$ plot and high $\mathrm{N}$ plot, to normalize the GNDVI measurements against a GNDVI for a well-fertilized area within the field. Doing this also normalized the confounding effects of various management (e.g., hybrid) and environmental (e.g., soil and precipitation) factors within the field, focusing sensor management on the specific $\mathrm{N}$ needs of the crop. They found that the sensor recognized differences in crop $\mathrm{N}$ status between plots that received no $\mathrm{N}$ at planting and plots that received $67 \mathrm{~kg} \mathrm{~N} \mathrm{ha}^{-1}$. They observed that, when too much $\mathrm{N}$ is applied before sensing, there was little or no difference in sensor values between corn from the well $\mathrm{N}$ 
fertilized reference and those where $\mathrm{N}$ was applied later. When SI values were around 0.9 , the analysis showed that another 50 to $125 \mathrm{~kg} \mathrm{~N}^{-1}$ was still needed to maximize profit. They explained this wide range in optimal $\mathrm{N}$ rates by noting that the crop was well fed with $\mathrm{N}$ at early growth stages, which is what the sensor "sees", although later, in advanced growth stages, the crop suffered an N shortage because at V12 the crop still requires substantial $\mathrm{N}$ to reach maturity and maximum yield potential. These findings highlight an important obstacle in using this technology to make an $\mathrm{N}$ diagnosis for season-long crop $\mathrm{N}$ needs using an early-season snapshot of crop $\mathrm{N}$ status. At side-dressing, even late side-dressing (V12), the crop still has time to reach physiological maturity, and many weather factors might influence yield between side-dressing and maturity, making the $\mathrm{N}$ need prediction difficult, particularly in southern states of the USA.

Kitchen et al. [113] found a weak relationship between optimal yield and SI but believed that the trend in the dataset could be used, empirically, to derive $\mathrm{N}$ application rates. On the other hand, their data suggested that the chlorophyll meter might be more effective in delineating subtle differences in crop $\mathrm{N}$ nutrition, as this instrument was able to detect differences in $\mathrm{N}$ nutrition much earlier in the growing season. This was because of the ground-based sensors, in considerable proportion, detect the upper leaves of the canopy, whereas the chlorophyll meter was used on the last fully expanded leaf, which is more likely to show $\mathrm{N}$ deficiency. They concluded that understanding $\mathrm{N}$ source and fate of $\mathrm{N}$ within fields is complex and were not able to offer a solid system of ideas to explain why their results were not consistent.

Dellinger et al. [125] examined the relationship between EONR and readings from the CC ACS-210 sensor and evaluated the potential for side-dress $\mathrm{N}$ recommendations. Their results suggested that the use of the GNDVI using this sensor would be limited to situations where there little or no N fertilizer was applied at planting. The EONR was correlated with the GNDVI when manure was applied at planting or when fertilizer was not applied at planting. However, when $56 \mathrm{~kg} \mathrm{~N} \mathrm{ha}^{-1}$ was applied at planting, the relationship between GNDVI and EONR was non-significant. They also found that a high $\mathrm{N}$ reference area at planting was needed for making side-dress $\mathrm{N}$ recommendations.

Raun et al. [92,105] developed methods for the use of a GBAO sensor to improve NUE in winter wheat. He utilized INSEY to relate GS red NDVI readings to wheat yield. The application of this methodology was effective because NDVI is a predictor of crop biomass accumulation and considers tiller mortality due to cold, dry winters [126]. The relationships in [92,127] showed that data were clumped within the graph, because the relationship between sensor reading and yield varied due to location, although the general trend was similar. The use of GBAO sensors has not been a supported $\mathrm{N}$ recommendation tool in North Dakota.

The relationship between sensor reading and yield is different in the corn production system compared to tillering mortality problems and exponential growth of corn begin about V6 compared to wheat [119]. Corn yield prediction is related to plant population, plant size, uptake of N at V6 [63]. Therefore, the yield can be estimated at V6 growth stage although some of the components of corn yield may already be established by V6 [128]. Fertilized kernel number per ear is related to the growth of corn at silking stage \pm 10 days [129]. Sensor readings obtained during silking are difficult because of saturation in the red spectra [29]. Vega and Sadras reported in 2003 that corn growth rate is positively and linearly related to the crop biomass during the critical periods of growth. Echarte and Andrade [130] stated that the harvest index was found similar for the corn varieties released between the times of 1965 to 1993 . This indicates that estimation of yield and potential for $\mathrm{N}$ response in relative terms is possible.

3.8.2. Use of LAI, Soil Moisture, Sensor Timing, Relationship Equations, and Crop Height to Improve Optical Sensor's Crop Yield Prediction Models

Several studies were conducted to improve the relationship between crop yield and sensor readings [65,106,107,131-133], however, their practical application is still in question due to their inconsistent results. 
Saturation-adjusted NDV [134] and combining crop models to NDVI [135] also improved NDVI yield prediction models. However, they failed to provide a commercial scale algorithm for farmers due to inconsistencies in their results. However, LAI has not been used to a level that could provide growers a stable and reliable sensor based in-season $\mathrm{N}$ application equation, and the apparent reason is measuring LAI is labor intensive. A recent study by Sharma et al. [65] on potatoes provided some promising results using estimated LAI from the sensor itself, which was found useful in improving the sensor and potato yield relationship and also solved the issue of red wavelength saturation with increased biomass. This is an important finding regarding solving the red wavelength saturation and improving the sensor and yield relationship using the same sensor from where NDVI readings were collected.

Improving sensor reading and crop yield relationship using soil moisture was studied in corn [136]. These studies were conducted using a soil moisture meter in a research plot. In both studies, the soil moisture multiplied with sensor readings improved its relationship with crop yield. However, it is impractical for farmers to use soil moisture meter data on a large farm. Therefore, precipitation data from local weather station might help to improve sensor and crop yield relationship. A study is needed to prove its applicability.

Plant height alone has also been used as a metric during the vegetative growth of corn. Corn plant height is influenced by the water content in the soil (Hussain et al., 1999) [137], soil texture [138], the rate of fertilizer application [106,108,139] and cultivation methods [138]. Measurement of plant height can be conducted using high-resolution ultrasound distance sensing of the crop canopy [140,141]. Sugar beet (Beta vulgaris L.) canopy height multiplied by a GS reading was used in Minnesota to better estimate leaf $\mathrm{N}$ concentration, sugar beet top $\mathrm{N}$ content and dry matter yield [142]. The NDVI measurement is related to leaf area index, which is a two-dimensional representation of crop growth and development. The NDVI measurement is related to leaf area index best at early to medium growth stages in corn, but the relationship becomes increasingly poor later in corn growth due to saturation of readings [143,144].

Since the N content of sugar beet tops is not only related to the two-dimensional leaf area but also its density, multiplying NDVI times canopy height results in a "leaf volume" instead of a leaf area index [145]. In experiments with other crop types with different leaf and growth architectures, NDVI measurements were related to plant height in alfalfa (Medicago sativa L.), where plant height and surface area coverage develop nearly simultaneously but were not related to plant height in grasses, where surface coverage was nearly continuous [146].

In a practical world with large field size, manual height measurement using sensor is impractical. Therefore, Sharma [147] did an extensive study in corn manual height and automated sensor height to improve the sensor relationship with the corn yield They used an acoustic sensor to measure height through a sensor which could be an answer to improve the adaptability of using crop height along with sensor built algorithms, but it needs further study to refine the height sensor models. In addition, North Dakota State University was the first institution to use red edge wavelength along with plant height [148] to create nitrogen recommendation based on the sensors. For pre-planting/at planting nitrogen recommendation, an $\mathrm{N}$ calculator [149] was developed based on economic return that helps farmer to use in-season sensor-based $\mathrm{N}$ recommendation

\section{Conclusions}

It is determined by this review that no one method that can be used individually, but a combined approach might help in improving NUE. In long-term prospectus, the use of optical sensors may help in improving NUE and farmer profit only when precise data are collected from multiple sites considering soil, climate, and cultural practice variability and then a robust yield predicting model is developed. Sensor-based in season nutrient management combined with a soil testing approach at the beginning of crop planting, and a split application might be the answer to improve nitrogen use efficiency. The improvement in sensor technology and algorithm development needs further research 
to develop more reliable and stable models. Precipitation data might help in improving sensor models due to the impracticality of soil moisture sensor data collection. Estimated LAI from the sensor has shown promising results but needs more research trials for robust data collection. More wavelength ranges other than red need to be tested to confirm their applicability on high biomass crop where red wavelength is saturated.

Acknowledgments: We acknowledge Mriganka De, a postdoctoral fellow at Iowa State University, for helping us in developing graphs for fertilizer use around the world.

Conflicts of Interest: The authors declare no conflict of interest.

\section{References}

1. Diaz, R.J.; Rosenberg, R. Spreading dead zones and consequences for marine ecosystems. Science 2008, 321, 926-929. [CrossRef] [PubMed]

2. Bouwman, L.; Goldewijk, K.K.; Van Der Hoek, K.W.; Beusen, A.H.W.; Van Vuuren, D.P.; Willems, J.; Rufino, M.C.; Stehfest, E. Exploring global changes in nitrogen and phosphorus cycles in agriculture induced by livestock production over the 1900-2050 period. Proc. Natl. Acad. Sci. USA 2013, 110, 20882-20887. [CrossRef] [PubMed]

3. Chien, S.H.; Teixeira, L.A.; Cantarella, H.; Rehm, G.W.; Grant, C.A.; Gearhart, M.M. Agronomic effectiveness of granular nitrogen/phosphorus fertilizers containing elemental sulfur with and without ammonium sulfate: A Review. Agron. J. 2016, 108, 1203. [CrossRef]

4. Dobermann, A.; Ping, J.L.; Adamchuk, V.I.; Simbahan, G.C.; Ferguson, R.B. Classification of Crop Yield Variability in Irrigated Production Fields. Agron. J. 2003, 95, 1105. [CrossRef]

5. Bundy, L.G. Nitrogen recommendations and optimum nitrogen rates: How do they compare? In Proceedings of the North Central Extension-Industry Soil Fertility Conference, St. Louis, MO, USA, 15-16 November 2000; Potash and Phosphate Institute: St. Louis, MO, USA; Brookings, SD, USA, 2000.

6. United States Department of Agriculture National Agricultural Statistics Service. Available online: https:/ /www.nass.usda.gov/ (accessed on 1 April 2017).

7. Zoubek, G.; Nygren, A. Giving Proper Nitrogen Credit for Legumes in Corn and Milo Rotations. Crop. News Arch. 2008, 1-3. Available online: https:// cropwatch.unl.edu/giving-proper-nitrogen-creditlegumes-corn-and-milo-rotations (accessed on 25 December 2017).

8. Walworth, J. AZ1591; College of Agriculture and Life Sciences, University of Arizona: Tucson, AZ, USA, 2013; p. 3.

9. Hurek, T.; Van Montagu, M.; Kellenberger, E.; Reinhold-Hurek, B. Induction of complex intracytoplasmic membranes related to nitrogen fixation in Azoarcus sp. BH72. Mol. Microbiol. 1995, 18, 225-236. [CrossRef] [PubMed]

10. Ma, F.; Ma, H.; Qiu, H.; Yang, H. Effects of water levels and the additions of different nitrogen forms on soil net nitrogen transformation rate and $\mathrm{N}_{2} \mathrm{O}$ emission in subtropical forest soils. J. Appl. Ecol. 2015, 26, 379-387.

11. Vinod, K.; Rawat, A.K.; Rao, D.L.N. Influence on soil carbon and nitrogen content in vertisols of madhya pradesh under different crop rotation. Q. Res. J. Plant Anim. Sci./Bhartiya Krishi Anusandhan Patrika 2016, 31, 108-113.

12. Hocking, M.D.; Reynolds, J.D. Nitrogen uptake by plants subsidized by Pacific salmon carcasses: A hierarchical experiment. Can. J. For. Res. 2012, 42, 908-917. [CrossRef]

13. Nogalska, A. Changes in the soil nitrogen content caused by direct and residual effect of meat and bone meal. J. Elemntol. 2013, 659-671. [CrossRef]

14. Sharma, L.; Bali, S.; Dwyer, J.; Plant, A.; Bhowmik, A. A case study of improving yield prediction and sulfur deficiency detection using optical sensors and relationship of historical potato yield with weather data in maine. Sensors 2017, 17, 1095. [CrossRef] [PubMed]

15. Occupational Safety and Health Administration (OSHA). Storage and Handling of Anhydrous Ammonia; Occupational Safety and Health Administration: Washington, DC, USA, 2017; pp. 1-28.

16. Pan, K.; Gong, P.; Wang, J.; Wang, Y.; Liu, C.; Li, W.; Zhang, L. Applications of nitrate and ammonium fertilizers alter soil nematode food webs in a continuous cucumber cropping system in Southwestern Sichuan, China. Eurasian J. Soil Sci. 2015, 4, 287-300. [CrossRef] 
17. Elvir, J.A.; Wiersma, G.B.; Bethers, S.; Kenlan, P. Effects of chronic ammonium sulfate treatment on the forest at the Bear Brook Watershed in Maine. Environ. Monit. Assess. 2010, 171, 129-147. [CrossRef] [PubMed]

18. Daigger, L.A.; Sander, D.H.; Peterson, G.A. Nitrogen content of winter wheat during growth and maturation. Agron. J. 1976, 68, 815-818. [CrossRef]

19. Volpe, V.; Giovannetti, M.; Sun, X.-G.; Fiorilli, V.; Bonfante, P. The phosphate transporters LjPT4 and MtPT4 mediate early root responses to phosphate status in non mycorrhizal roots. Plant Cell Environ. 2016, 39, 660-671. [CrossRef] [PubMed]

20. Choi, J.-H.; Maruthamuthu, S.; Lee, H.-G.; Ha, T.-H.; Bae, J.-H. Nitrate removal by electro-bioremediation technology in Korean soil. J. Hazard. Mater. 2009, 168, 1208-1216. [CrossRef] [PubMed]

21. Koffi, D.; Vincent, B.; Valere, M. Yield and nitrogen use efficiency of aromatic rice varieties in response to nitrogen fertilizer. Emir. J. Food Agric. 2016, 28, 126-135. [CrossRef]

22. Daniel, F.B.; Griffith, M.B.; Troyer, M.E. Influences of spatial scale and soil permeability on relationships between land cover and baseflow stream nutrient concentrations. Environ. Manag. 2010, 45, 336-350. [CrossRef] [PubMed]

23. Matejek, B.; Huber, C.; Dannenmann, M.; Kohlpaintner, M.; Gasche, R.; Göttlein, A.; Papen, H. Microbial nitrogen-turnover processes within the soil profile of a nitrogen-saturated spruce forest and their relation to the small-scale pattern of seepage-water nitrate. J. Plant Nutr. Soil Sci. 2010, 173, 224-236. [CrossRef]

24. Peltonen, J.; Virtanen, A.; Haggrèn, E. Using a chlorophyll meter to optimize nitrogen fertilizer application for intensively-managed small-grain cereals. J. Agron. Crop Sci. 1995, 174, 309-318. [CrossRef]

25. Raun, W.R.; Johnson, G.V. Improving nitrogen use efficiency for cereal production. Agron. J. 1999, 91, 357-363. [CrossRef]

26. Scharf, P.C.; Lory, J.A. Calibrating corn color from aerial photographs to predict sidedress nitrogen need. Agron. J. 2002, 94, 397-404. [CrossRef]

27. Cassman, K.G.; Dobermann, A.; Walters, D.T. Agroecosystems, nitrogen-use efficiency, and nitrogen management. AMBIO 2002, 31, 132-140. [CrossRef] [PubMed]

28. Abebe, Z.; Feyisa, H. Effects of Nitrogen Rates and Time of Application on Yield of Maize: Rainfall Variability Influenced Time of N Application. Int. J. Agron. 2017, 2017, 1-10. [CrossRef]

29. Schröder, J.J.; Neeteson, J.J.; enema, O.O.; Struik, P.C. Does the crop or the soil indicate how to save nitrogen in maize production?: Reviewing the state of the art. Field Crops Res. 2000, 66, 151-164. [CrossRef]

30. Cameron, K.C.; Di, H.J.; Moir, J.L. Nitrogen losses from the soil/plant system: a review. Ann. Appl. Biol. 2013, 162, 145-173. [CrossRef]

31. Reddy, G.B.; Reddy, K.R. Fate of Nitrogen-15 Enriched Ammonium Nitrate Applied to Corn. Soil Sci. Soc. Am. J. 1993, 57, 111-115. [CrossRef]

32. Olson, R.A.; Raun, W.R.; Chun, Y.S.; Skopp, J. Nitrogen Management and Interseeding Effects on Irrigated Corn and Sorghum and on Soil Strength. Agron. J. 1986, 78, 856. [CrossRef]

33. Keeney, D.R. Nitrogen Management for Maximum Efficiency and Minimum Pollution Farmed Soils, Fertilizer, Agro-Ecosystems; American Society of Agronomy: Madison, WI, USA, 1982.

34. Mamo, M.; Malzer, G.L.; Mulla, D.J.; Huggins, D.R.; Strock, J. Spatial and Temporal Variation in Economically Optimum Nitrogen Rate for Corn. Agron. J. 2003, 95, 958-964. [CrossRef]

35. Inman, D.; Khosla, R.; Westfall, D.G.; Reich, R. Nitrogen uptake across site specific management zones in irrigated corn production systems. Agron. J. 2005, 97, 169-176. [CrossRef]

36. Dobermann, A.; Cassman, K.G. Plant nutrient management for enhanced productivity in intensive grain production systems of the United States and Asia. Plant Soil 2002, 247, 153-175. [CrossRef]

37. Franzen, D.W.; Hopkins, D.H.; Sweeney, M.D.; Ulmer, M.K.; Halvorson, A.D. Evaluation of Soil Survey Scale for Zone Development of site-specific nitrogen management. Agron. J. 2002, 94, 381-389. [CrossRef]

38. Flowers, M.; Weisz, R.; White, J.G. Yield-based management zones and grid sampling strategies. Agron. J. 2005, 97, 968-982. [CrossRef]

39. Kitchen, N.R.; Sudduth, K.A.; Myers, D.B.; Drummond, S.T.; Hong, S.Y. Delineating productivity zones on claypan soil fields using apparent soil electrical conductivity. Comput. Electron. Agric. 2005, 46, 285-308. [CrossRef]

40. Schepers Aaron, R.; Shanahan John, F.; Liebig Mark, A.; Schepers James, S.; Johnson, S.; Ariovaldo, L., Jr. Appropriateness of management zones for characterizing spatial. Agron. J. 2004, 96, 195-203. [CrossRef] 
41. Wibawa, W.D.; Dludlu, D.L.; Swenson, L.J.; Hopkins, D.G.; Dahnke, W.C. Variable Fertilizer Application Based on Yield Goal, Soil Fertility, and Soil Map Unit. J. Prod. Agric. 1993, 6, 255-261. [CrossRef]

42. Alexandra, N.; Kravchenko, D.G.B.; Bullock, D.G. Correlation of corn and soybean grain yield with topography and soil properties. Agron. J. 1949, 92, 75-83.

43. Jaynes, D.B.; Colvin, T.S. Spatiotemporal variability of corn and soybean yield. Agron. J. 1997, 89, 30-37. [CrossRef]

44. Lambert, D.M.; Lowenberg-DeBoer, J.; Malzer, G.L. Economic analysis of spatial-temporal patterns in corn and soybean response to nitrogen and phosphorus. Agron. J. 2006, 98, 43-54. [CrossRef]

45. Bibi, S.; Saifullah; Naeem, A.; Dahlawi, S. Environmental Impacts of Nitrogen Use in Agriculture, Nitrate Leaching and Mitigation Strategies. In Soil Science: Agricultural and Environmental Prospectives; Springer International Publishing: Cham, Switzerland, 2016; pp. 131-157.

46. Gastal, F.; Lemaire, G. N uptake and distribution in crops: An agronomical and ecophysiological perspective. J. Exp. Bot. 2002, 53, 789-799. [CrossRef] [PubMed]

47. Havlin, J.L.; Jacobsen, J.S.; Rice, C.W.; Havlin, J.L. Integrating Mineralizable Nitrogen Indices into Fertilizer Nitrogen Recommendations. In Soil Testing: Prospects for Improving Nutrient Recommendations; Soil Science Society of America/American Society of Agronomy: Madison, WI, USA, 1994; Volume 40, pp. 1-13.

48. Follett, R.F.; Keeney, D.R.; Cruse, R.M.; Schepers, J.S.; Mosier, A.R. Accounting for Nitrogen in Nonequilibrium Soil-Crop Systems. In Managing Nitrogen for Groundwater Quality and Farm Profitability; Soil Science Society of America: Washington, DC, USA, 1991; pp. 125-138.

49. Puntel, L.A.; Sawyer, J.E.; Barker, D.W.; Dietzel, R.; Poffenbarger, H.; Castellano, M.J.; Moore, K.J.; Thorburn, P.; Archontoulis, S.V. Modeling Long-Term Corn Yield Response to Nitrogen Rate and Crop Rotation. Front. Plant Sci. 2016, 7, 1630. [CrossRef] [PubMed]

50. Fox, R.H.; Piekielek, W.P. The Relationship between Corn Grain Yield Goals and Economic Optimum Nitrogen Fertilizer Rates; Pennsylvania State University: Pennsylvania, PA, USA, 1995.

51. Kachanoski, R.G.; O’halloran, L.; Aspinall, D.; Bertoldi, P. Von delta yield: Mapping fertilizer nitrogen requirement for crops. Better Crops 1996, 80, 20-23.

52. Inada, K. Studies for a method for determining the deepness of green color and chlorophyll content of intact crop leaves and its practical application. 2. Photoelectric characters of chlorophyll meter and correlation between the reading and chlorophyll content in leaves. Proc. Crop Sci. Soc. Jpn. 1965, 33, 301-308.

53. Sinclair, T.R.; Horie, T. Leaf nitrogen, photosynthesis, and crop radiation use efficiency: A review. Crop Sci. 1989, 29, 90-98. [CrossRef]

54. Ulrich, A. Physiological bases for assessing the nutritional requirements of plants. Ann. Rev. Plant Physiol. 1952, 3, 207-228. [CrossRef]

55. Schepers, J.S.; Blackmer, T.M.; Francis, D.D. Predicting N fertilizer needs for corn in humid regions: Using chlorophyll meters. In Predicting N Fertilizer Needs for Corn in Humid Regions; Bock, B.R., Kelley, K.R., Eds.; National Fertilizer and Environmental Research Center: Muscle Shoals, AL, USA, 1992; pp. 105-114.

56. Greenwood, D.J.; Lemaire, G.; Gosse, G.; Cruz, P.; Draycott, A.; Neeteson, J.J. Decline in Percentage N of C3 and C4 Crops with Increasing Plant Mass. Ann. Bot. 1990, 66, 425-436. [CrossRef]

57. Justes, E.; Mary, B.; Meynard, J.-M.; Machet, J.-M.; Thelier-Huche, L. Determination of a critical nitrogen dilution curve for winter wheat crops. Ann. Bot. 1994, 74, 397-407. [CrossRef]

58. Van Oosterom, E.J.; Carberry, P.S.; Muchow, R.C. Critical and minimum N contents for development and growth of grain sorghum. Field Crops Res. 2001, 70, 55-73. [CrossRef]

59. Sheehy, J.E.; Dionora, M.J.A.; Mitchell, P.L.; Peng, S.; Cassman, K.G.; Lemaire, G.; Williams, R.L. Critical Nitrogen Concentrations: Implications for High-Yielding Rice (Oryza sativa L.) Cultivars in the Tropics. Field Crops Res. 1998, 59, 31-41. [CrossRef]

60. Lemaire, G.; Salette, J. Relation entre dynamique de croissance et dynamique de prélèvement d'azote pour un peuplement de graminées fouragères: I. Etude de l'effect du milieu. Agron. J. 1984, 4, 423-430. [CrossRef]

61. Binford, G.D.; Blackmer, A.M.; Cerrato, M.E. Relationships between corn yields and soil nitrate in late spring. Agron. J. 1992, 84, 53-59. [CrossRef]

62. Plénet, D.; Lemaire, G. Relationships between dynamics of nitrogen uptake and dry matter accumulation in maize crops. Determination of critical N concentration. Plant Soil 1999, 216, 65-82. [CrossRef]

63. Herrmann, A.; Taube, F. The range of the critical nitrogen dilution curve for maize (Zea mays L.) can be extended until silage maturity. Agron. J. 2004, 96, 1131-1138. [CrossRef] 
64. Kravchenko, A.N.; Robertson, G.P.; Thelen, K.D.; Harwood, R.R. Management, topographical, and weather effects on spatial variability of crop grain yields. Agron. J. 2005, 97, 514-523. [CrossRef]

65. Bu, H.; Sharma, L.K.; Denton, A.; Franzen, D.W. Comparison of satellite imagery and ground-based active optical sensors as yield predictors in sugar beet, spring wheat, corn, and sunflower. Agron. J. 2017, 109, 299-308. [CrossRef]

66. Jiang, P.; Thelen, K.D. Effects of soil and topographic properties on crop yield in a north-central corn-soybean cropping system. Agron. J. 2004, 96, 252-258. [CrossRef]

67. Ginting, D.; Moncrief, J.F.; Gupta, S.C. Performance of a variable tillage system based on interactions with landscape and soil. Precis. Agric. 2003, 4, 19-34. [CrossRef]

68. Fox, R.H.; Kern, J.M.; Piekielek, W.P. Nitrogen fertilizer source, and method and time of application effects on no-till corn yields and nitrogen uptakes. Agron. J. 1986, 78, 741-746. [CrossRef]

69. Bandel, V.A.; Dzienia, S.; Stanford, G. Comparison of N Fertilizers for No-Till Corn1. Agron. J. 1980, $72,337$. [CrossRef]

70. Ewing, P.M.; Runck, B.C. Optimizing nitrogen rates in the midwestern United States for maximum ecosystem value. Ecol. Soc. 2015, 20, 1-14. [CrossRef]

71. Holland, K.H.; Schepers, J.S. Derivation of a variable rate nitrogen application model for in-season fertilization of corn. Agron. J. 2010, 102, 1415-1424. [CrossRef]

72. Binder, D.L.; Sander, D.H.; Walters, D.T. Maize Response to Time of Nitrogen Application as Affected by Level of Nitrogen Deficiency. Agron. J. 2000, 92, 1228-1236. [CrossRef]

73. Cowling, S.A.; Field, C.B. Environmental control of leaf area production: Implications for vegetation and land-surface modeling. Glob. Biogeochem. Cycles 2003, 17, 7-1-7-14. [CrossRef]

74. Whittaker, R.H.; Marks, P.L. Methods of assessing terrestrial productivity. In Primary Productivity of the Biosphere; Lieth, H., Whittaker, R.H., Eds.; Ecological Studies 14; Springer: Berlin/Heidelberg, Germany, 1975; pp. 55-118.

75. Anten, N.P.R.; Schieving, F.; Medina, E.; Werger, M.J.A.; Schuffelen, P. Optimal leaf area indices in C3 and C4 mono- and dicotyledonous species at low and high nitrogen availability. Physiol. Plant. 1995, 95, 541-550. [CrossRef]

76. Weiss, M.; Baret, F. Evaluation of canopy biophysical variable retrieval performances form the accumulation of large swath satellite data. Remote Sens. Environ. 1999, 70, 293-306. [CrossRef]

77. Wiegand, C.L.; Richardson, A.J.; Kanemasu, E.T. Leaf area index estimates for wheat from landsat and their implications for evapotranspiration and crop modeling. Agron. J. 1979, 71, 336-342. [CrossRef]

78. Curran, P.J. Multispectral remote sensing for the estimation of green leaf area index. Philos. Trans. R. Soc. 1983, 309, 257-270. [CrossRef]

79. Fang, H.; Liang, S.; Kuusk, A. Retrieving leaf area index using a genetic algorithm with a canopy radiative transfer model. Remote Sens. Environ. 2003, 85, 257-270. [CrossRef]

80. Carter, G.A. Responses of leaf spectral reflectance to plant stress. Am. J. Bot. 1993, 80, 239-243. [CrossRef]

81. Carter, G.A.; Knapp, A.K. Leaf optical properties in higher plants: Linking spectral characteristics to stress and chlorophyll concentration. Am. J. Bot. 2001, 88, 677-684. [CrossRef] [PubMed]

82. Zhao, D.; Reddy, K.R.; Kakani, V.G.; Read, J.J.; Carter, G.A. Corn (Zea mays L.) growth, leaf pigment concentration, photosynthesis and leaf hyperspectral reflectance properties as affected by nitrogen supply. Plant Soil 2003, 257, 205-217. [CrossRef]

83. Masoni, A.; Ercoli, L.; Mariotti, M. Spectral properties of leaves deficient in iron, sulfur, magnesium, and manganese. Agron. J. 1996, 88, 937-943. [CrossRef]

84. Belay, A.; Claassens, A.; Wehner, F. Effect of direct nitrogen and potassium and residual phosphorus fertilizers on soil chemical properties, microbial components and maize yield under long-term crop rotation. Biol. Fertil. Soils 2002, 35, 420-427.

85. Ma, B.L.; Morrison, M.J.; Dwyer, L.M. Canopy light reflectance and field greenness to assess nitrogen fertilization and yield of maize. Agron. J. 1996, 88, 915-920. [CrossRef]

86. Wolfe, D.W.; Henderson, D.W.; Hsiao, T.C.; Alvino, A. Interactive Water and Nitrogen Effects on Senescence of Maize. II. Photosynthetic decline and longevity of individual leaves. Agron. J. 1988, 80, 865-870. [CrossRef]

87. Gentry, L.E.; Below, F.E. Corn productivity as influence by form and availability of nitrogen. Crop Sci. 1993, 33, 491-497. [CrossRef] 
88. Schepers, J.; VanToai, T.; Shanahan, J.F.; Holland, K.H.; Schepers, J.S.; Francis, D.D.; Schlemmer, M.R.; Caldwell, R. Use of a Crop Canopy Reflectance Sensor to Assess Corn Leaf Chlorophyll Content. In Digital Imaging and Spectral Techniques: Applications to Precision Agriculture and Crop Physiology; American Society of Agronomy/Crop Science Society of America/Soil Science Society of America: Madison, WI, USA, 2003; Volume 66, pp. 135-150.

89. Hansen, P.M.; Schjoerring, J.K. Reflectance measurement of canopy biomass and nitrogen status in wheat crops using normalized difference vegetation indices and partial least squares regression. Remote Sens. Environ. 2003, 86, 542-553. [CrossRef]

90. Gitelson, A.A.; Viña, A.; Arkebauer, T.J.; Rundquist, D.C.; Keydan, G.P.; Gitelson, A.A.; Arkebauer, T.J.; Rundquist, D.C.; Leavitt, B.; Keydan, G. Remote estimation of leaf area index and green leaf biomass in maize canopies. Geophys. Res. Lett. 2003, 30, 51-52. [CrossRef]

91. Moges, S.M.; Raun, W.R.; Mullen, R.W.; Freeman, K.W.; Johnson, G.V.; Solie, J.B. Evaluation of green, red, and near infrared bands for predicting winter wheat biomass, nitrogen uptake, and final grain yield. J. Plant Nutr. 2005, 27, 1431-1441. [CrossRef]

92. Raun, W.R.; Solie, J.B.; Johnson, G.V.; Stone, M.L.; Lukina, E.V.; Thomason, W.E.; Schepers, J.S. In-season prediction of potential grain yield in winter wheat using canopy reflectance. Agron. J. 2001, 93, 131-138. [CrossRef]

93. Inman, D.; Khosla, R.; Reich, R.M.; Westfall, D.G. Active remote sensing and grain yield in irrigated maize. Precis. Agric. 2007, 8, 241-252. [CrossRef]

94. Hatfield, J.L.; Gitelson, A.A.; Schepers, J.S.; Walthall, C.L. Application of spectral remote sensing for agronomic decisions. Agron. J. 2008, 257, 117-131. [CrossRef]

95. Henebry, G.M.; de Beurs, K.M.; Gitelson, A.A. Land surface phenologies of Uzbekistan and Turkmenistan between 1982 and 1999. Arid Ecosyst. 2005, 11, 25-32.

96. Osborne, S.L.; Schepers, J.S.; Francis, D.D.; Schlemmer, M.R. Use of spectral radiance to estimate in-season biomass and grain yield in nitrogen- and water-stressed corn. Crop Sci. 2002, 42, 165-171. [CrossRef] [PubMed]

97. Blackmer, T.M.; Schepers, J.S.; Varvel, G.E.; Meyer, G.; Meyer, G.E. Analysis of Aerial Photography for Nitrogen Stress within Corn Fields. Agron. J. 1996, 88, 729-733. [CrossRef]

98. Blackmer, T.; Schepers, J.S.; Varvel, G.E.; Walter-Shea, E.A.; Blackmer, T.M. Nitrogen deficiency detection using reflected shortwave radiation from irrigated corn canopies agroclimatology nitrogen deficiency detection using reflected shortwave radiation from irrigated corn canopies. Agron. J. 1996, 88. [CrossRef]

99. Kitchen, N.R.; Goulding, K.W. On-farm technologies and practices to improve nitrogen use efficiency. In Nitrogen in the Environment: Sources, Problems, and Management; Follett, R.F., Hatfield, J.L., Eds.; Elsevier Science: Amsterdam, The Netherlands, 2001; pp. 335-369.

100. Scharf, P.C.; Brouder, S.M.; Hoeft, R.G. Chlorophyll meter readings can predict nitrogen need and yield response of corn in the North-Central USA. Agron. J. 2006, 98, 655-665. [CrossRef]

101. Varvel, G.E.; Schepers, J.S.; Francis, D.D. Ability for in-season correction of nitrogen deficiency in corn using chlorophyll meters. Soil Sci. Soc. Am. J. 1997, 61, 1233-1239. [CrossRef]

102. Bullock, D.G.; Anderson, D.S. Evaluation of the Minolta SPAD-502 chlorophyll meter for nitrogen management in corn. J. Plant Nutr. 1998, 21, 741-755. [CrossRef]

103. Scharf, P.C. Soil and plant tests to predict optimum nitrogen rates for corn. J. Plant Nutr. 2001, 24, 805-826. [CrossRef]

104. Scharf, P.C.; Lory, J.A. Calibrating Reflectance Measurements to predict optimal sidedress nitrogen rate for corn. Agron. J. 2009, 101, 615-625. [CrossRef]

105. Raun, W.R.; Solie, J.B.; Johnson, G.V.; Stone, M.L.; Mullen, R.W.; Freeman, K.W.; Thomason, W.E.; Lukina, E.V. Improving nitrogen use efficiency in cereal grain production with optical sensing and variable rate application. Agron. J. 2002, 94, 815. [CrossRef]

106. Sharma, L.K.; Bu, H.; Franzen, D.W.; Denton, A. Use of corn height measured with an acoustic sensor improves yield estimation with ground based active optical sensors. Comput. Electron. Agric. 2016, 124, 254-262. [CrossRef] 
107. Bu, H.; Sharma, L.K.; Denton, A.; Franzen, D.W. Sugar Beet Yield and Quality Prediction at Multiple Harvest Dates Using Active-Optical Sensors. Agron. J. 2016, 108, 273-284. [CrossRef]

108. Sharma, L.K.; Franzen, D.W. Use of corn height to improve the relationship between active optical sensor readings and yield estimates. Precis. Agric. 2014, 15, 331-345. [CrossRef]

109. Sharma, L.K. Evaluation of Active Optical Ground-Based Sensors to Detect Early Nitrogen Deficiencies in Corn. Ph.D. Thesis, North Dakota State University, Fargo, ND, USA, 2014.

110. Sharma, L.K.; Bu, H.; Franzen, D.W. Comparison of two ground-based active-optical sensors for in-season estimation of corn (Zea mays L.) yield. J. Plant Nutr. 2016, 39, 957-966. [CrossRef]

111. Shaver, T.; Khosla, R.; Westfall, D. Evaluation of two crop canopy sensors for nitrogen recommendations in irrigated maize. J. Plant Nutr. 2014, 37, 406-419. [CrossRef]

112. Smil, V. Nitrogen in crop production: An account of global flows. Global Biogeochem. Cycles 1999, 13, 647-662. [CrossRef]

113. Kitchen, N.R.; Sudduth, K.A.; Drummond, S.T.; Scharf, P.C.; Palm, H.L.; Roberts, D.F.; Vories, E.D. Ground-based canopy reflectance sensing for variable-rate nitrogen corn fertilization. Agron. J. 2010, 102, 71-84. [CrossRef]

114. Knipling, E.B. Physical and physiological basis for the reflectance of visible and near near-infrared radiation from vegetation. Remote Sens. Environ. 1970, 1, 155-159. [CrossRef]

115. Daughtry, C.S.T.; Walthall, C.L.; Kim, M.S.; De Colstoun, E.B.; Mcmurtrey, J.E., III. Estimating corn leaf chlorophyll concentration from leaf and canopy reflectance. Remote Sens. Environ. 2000, 74, 229-239. [CrossRef]

116. Gilabert, M.A.; Gandía, S.; Meliá, J. Remote Sensing of Environment; American Elsevier Pub. Co.: Atlanta, GA, USA, 1969; Volume 55.

117. Mullen, R.W.; Freeman, K.W.; Raun, W.R.; Johnson, G.V.; Stone, M.L.; Solie, J.B. Identifying an in-season response index and the potential to increase wheat yield with nitrogen. Agron. J. 2003, 95, 347-351. [CrossRef]

118. Shanahan, J.F.; Kitchen, N.R.; Raun, W.R.; Schepers, J.S. Responsive in-season nitrogen management for cereals. Comput. Electron. Agric. 2008, 61, 51-62. [CrossRef]

119. Gitelson, A.A.; Kaufman, Y.J.; Merzlyak, M.N. Remote Sensing of Environment; American Elsevier Pub. Co.: Atlanta, GA, USA, 1969; Volume 58.

120. Clay, D.E.; Kim, K.-I.; Chang, J.; Clay, S.A.; Dalsted, K. Characterizing water and nitrogen stress in corn using remote sensing. Agron. J. 2006, 98, 579-587. [CrossRef]

121. Shanahan, J.; Schepers, J.S.; Francis, D.D.; Varvel, G.E.; Wilhelm, W.; Shanahan, A.J.; Tringe, J.M.; Schlemmer, M.R.; Major, D.J. Use of remote-sensing imagery to estimate corn grain yield. Agron. J. 1988, 17, 583-589. [CrossRef]

122. Martin, K.L.; Girma, K.; Freeman, K.W.; Teal, R.K.; Tubańa, B.; Arnall, D.B.; Chung, B.; Walsh, O.; Solie, J.B.; Stone, M.L.; et al. Expression of variability in corn as influenced by growth stage using optical sensor measurements. Agron. J. 2007, 99, 384-389. [CrossRef]

123. Solari, F.; Shanahan, J.; Ferguson, R.; Schepers, J.; Gitelson, A. Active sensor reflectance measurements of corn nitrogen status and yield potential. Agron. J. 2008, 100, 571-579. [CrossRef]

124. Freeman, K.W.; Girma, K.; Arnall, D.B.; Mullen, R.W.; Martin, K.L.; Teal, R.K.; Raun, W.R. By-plant prediction of corn forage biomass and nitrogen uptake at various growth stages using remote sensing and plant height. Agron. J. 2007, 99, 530-536. [CrossRef]

125. Dellinger, A.E.; Schmidt, J.P.; Beegle, D.B. Developing nitrogen fertilizer recommendations for corn using an active sensor. Agron. J. 2008, 100, 1546-1552. [CrossRef]

126. Deering, D.W. Measuring forage production of grazing units from Landsat MSS data. In Proceedings of the 10th International Symposium on Remote Sensing of Environment, Ann Arbor, MI, USA, 6-10 October 1975; Environmental Research Institute of Michigan: Ann Arbor, MI, USA, 1975; pp. 1169-1178.

127. Lukina, E.V.; Freeman, K.W.; Wynn, K.J.; Thomason, W.E.; Mullen, R.W.; Stone, M.L.; Solie, J.B.; Klatt, A.R.; Johnson, G.V.; Elliott, R.L.; et al. Nitrogen fertilization optimization algorithm based on in-season estimates of yield and plant nitrogen uptake. J. Plant Nutr. 2001, 24, 885-898. [CrossRef] 
128. Pagano, E.; Cela, S.; Maddonni, G.A.; Otegui, M.E. Intra-specific competition in maize: Ear development, flowering dynamics and kernel set of early-established plant hierarchies. Field Crops Res. 2007, 102, 198-209. [CrossRef]

129. Andrade, F.H.; Vega, C.; Uhart, S.; Cirilo, A.; Cantarero, M.; Valentinuz, O. Kernel number determination in maize. Crop Sci. 1999, 39, 453-459. [CrossRef]

130. Echarte, L.; Andrade, F.H. Harvest index stability of Argentinean maize hybrids released between 1965 and 1993. Field Crops Res. 2003, 82,1-12. [CrossRef]

131. Bragagnolo, J.; Amado, T.J.C.; da Silveira Nicoloso, R.; Jasper, J.; Kunz, J.; de Gregori Teixeir, T. Optical crop sensor for variable-rate nitrogen fertilization in corn: I-Plant nutrition and dry matter production. Rev. Bras. Ciência do Solo 2013, 37, 1288-1298. [CrossRef]

132. Ngelo Rodrigues, M. Establishment of Continuous Critical Levels for Indices of Plant and Presidedress Soil Nitrogen Status in the Potato Crop. Commun. Soil Sci. Plant Anal. 2004, 35, 2067-2085. [CrossRef]

133. Franzen, D.W.; Sharma, L.K.; Bu, H.; Dentond, A. Evidence for the ability of active-optical sensors to detect sulfur deficiency in corn. Agron. J. 2016, 108, 2158-2162. [CrossRef]

134. Gu, Y.; Wylie, B.K.; Howard, D.M.; Phuyal, K.P.; Ji, L. NDVI saturation adjustment: A new approach for improving cropland performance estimates in the Greater Platte River Basin, USA. Ecol. Indic. 2013, 30, 1-6. [CrossRef]

135. Hoefsloot, P.; Ines, A.; Dam, J.C.; van Joseph, C.; Duveiller, G.; Kayitakire, F.; Hansen, J. Combining Crop Models and Remote Sensing for Yield Prediction: Concepts, Applications and Challenges for Heterogeneous Smallholder Environments; Report of CCFAS-JRC Workshop at Joint Research Centre, Ispra, Italy, 13-14 June 2012; Publications Office of the European Union: Luxembourg, 2012. Available online: http:/ / publications.jrc.ec. europa.eu/repository/bitstream/JRC77375/lbna25643enn.pdf (accessed on 25 December 2017).

136. Walsh, O.S.; Klatt, A.R.; Solie, J.B.; Godsey, C.B.; Raun, W.R. Use of soil moisture data for refined GreenSeeker sensor based nitrogen recommendations in winter wheat (Triticum aestivum L.). Precis. Agric. 2013, 14, 343-356. [CrossRef]

137. Hussain, I.; Olson, K.R.; Ebelhar, S.A. Impacts of tillage and no-till on production of maize and soybean on an eroded Illinois silt loam soil. Soil Tillage Res. 1999, 52, 37-49. [CrossRef]

138. Kladivko, E.J.; Mackay, A.D.; Bradford, J.M. Earthworms as a factor in the reduction of soil crusting. Soil Sci. Soc. Am. J. 1986, 50, 191-196. [CrossRef]

139. Kapusta, G.; Krausz, R.F.; Matthews, J.L. Corn Yield is Equal in Conventional, Reduced, and No Tillage after 20 Years. Agron. J. 1996, 88, 812-817. [CrossRef]

140. Shrestha, D.S. Development of a Machine Vision System for Corn Plant Population, Spacing and Height Measurement; Iowa State University Ames: Ames, IA, USA, 2004.

141. Katsvairo, T.W.; Cox, W.J.; Van Es, H.M.; Glos, M. Spatial Yield Response of Two Corn Hybrids at Two Nitrogen Levels. Agron. J. 2003, 95, 1012-1022. [CrossRef]

142. Franzen, D.W.; Wagner, G.; Sims, A. Application of a ground-based sensor to determine N credits from sugarbeet. In Sugarbeet Research and Extension Reports; Sugarbeet Research and Education Board of Minnesota and North Dakota: Fargo, ND, USA, 2003; Volume 34, pp. 119-123.

143. Wilhelm, W.; Ruwe, K.; Schlemmer, M.R. Comparisons of three leaf area index meters in a corn canopy. Crop Sci. 2000, 40, 1179-1183. [CrossRef]

144. Haboudane, D.; Miller, J.R.; Pattey, E.; Zarco-Tejada, P.J.; Strachan, I.B. Hyperspectral vegetation indices and novel algorithms for predicting green LAI of crop canopies: Modeling and validation in the context of precision agriculture. Remote Sens. Environ. 2003, 90, 337-352. [CrossRef]

145. Liu, K.; Zhou, Q.; Wu, W.; Xia, T.; Tang, H. Estimating the crop leaf area index using hyperspectral remote sensing. J. Integr. Agric. 2016, 15, 475-491. [CrossRef]

146. Payero, J.O.; Neale, C.M.U.; Wright, J.L.; Wright, J.L. Comparison of eleven vegetation indices for estimating plant height of alfalfa and grass. Appl. Eng. Agric. 2003, 20, 385-393. [CrossRef]

147. Sharma, L.; Bu, H.; Denton, A.; Franzen, D. Active-optical sensors using red NDVI compared to red edge NDVI for prediction of corn grain yield in North Dakota, U.S.A. Sensors 2015, 15, 27832-27853. [CrossRef] [PubMed] 
148. Franzen, D.W.; Sharma, L.K.; Bu, H. Active Optical Sensor Algorithms for Corn Yield Prediction and a Corn Side-Dress Nitrogen Rate Aid; North Dakota State University Extension Service: Fargo, ND, USA, 2014.

149. Franzen, D.W.; Ashley, R.; Endres, G.; Teboh, J.; Sharma, L.K.; Bu, H.; Schmidt, B.; Schultz, E.C.; Lamb, J.; Heard, J.; et al. North Dakota Corn Nitrogen Calculator. 2015. Available online: https:/ /www.ndsu.edu/ pubweb/soils/corn/ (accessed on 14 November 2017). 